\section{Bioformulations and nano product from Chaetomium cupreum CC3003 to control leaf spot of rice var. Sen Pidoa in Cambodia}

\author{
Huyly Tann, Kasem Soytong \\ Department of Plant Production \\ Technology, Faculty of Agricultural \\ Technology, King Mongkut's Institute of \\ Technology Ladkrabang Bangkok, \\ Thailand
}

\section{Abstract}

Curvularia lunata was isolated from leaf spot of rice var. Sen Pidoa and tested for pathogenicity. Chaetomium cupreum CC3003 expressed antifungal activity against $C$. lunata in dual culture test. Hexane-crude extract, Et0Ac-crude extract and methanol-crude extract from $C$. cupreum inhibited sporulation of $C$. lunata with $\mathrm{ED}_{50}$ of $6.41,0.83$ and 7.81 $\mu \mathrm{g} / \mathrm{mL}$, respectively. Pot experiment revealed that plant heights in treated with a spore suspension of $C$. cupreum, bioformulation of $C$. cupreum, nano product from $C$. cupreum and tebuconazole were not significantly different when compared to the inoculated control. Disease reduction compared to the inoculated control from treatment with a spore suspension of Chaetomium, bioformulation of $C$. cupreum, nano product from $C$. cupreum and tebuconazole ranged between $41.66 \%$ to $58.33 \%$. Field experiment indicated that chemical method was decreased leaf spots infection by $60 \%$, followed by organic method (40\%) and GAP methods (40\%), respectively. The chemical and GAP methods were significantly higher in grain weight than the organic method when compared to the non-treated control. This is the first report using $C$. cupreum to control leaf spot of rice var. Sen Pidoa caused by $C$. lunata in Cambodia.

\section{Introduction}

Rice (Oryza sativa L) is one of the major food crops in Asia where it is the daily diet more than in other regions of the world. The major problems causing reductions in the quality and quantity of rice include pathogens and insect pests. Observation and preliminary disease diagnosis found that a leaf spot of rice caused by Curvularia lunata has become one of the most serious diseases of this crop in Cambodia especially in the rice var. Sen
Pidoa. ${ }^{1}$ It has been reported that $C$. lunata caused leaf spot for the first time in India, and that symptom showed brown leaf spot and finally blight. Moreover, it has been demonstrated that $C$. lunata caused many symptoms in rice e.g. grain discoloration, ${ }^{2}$ leaf spot, ${ }^{3}$ black kernel and seedling blight. ${ }^{4}$ Sheath rot of rice was reported for the first time in Tamil Nadu, India. ${ }^{5}$ Curvularia lunata causing leaf spots on Sorghum bicolor was also reported for the first time in Pakistan. ${ }^{6}$ Biological control of plant diseases has widely contributed to the reduction of the use of toxic chemical fungicides by farmers that pollute the environment and Harmon-target organisms. Chaetomium sp., belonging to the Ascomycota, has been reported as a biocontrol agent against several plant pathogens. ${ }^{7,8}$ Chaetomium globosum and C. cupreum have been successfully applied to control rice blast caused by Pyricularia oryzae. ${ }^{9}$

The objective was to evaluate Chaetomium cupreum CC3003 as a biocontrol agent to control leaf spot of rice var. Sen Pidoa caused by Curvularia lunata.

\section{Materials and Methods}

\section{Isolation of pathogen and patho- genicity test}

The pathogen was isolated from leaf spots of rice var. Sen Pidoa in Cambodia by using the tissue transplanting technique which followed the method of Tann et al., ${ }^{10}$ and morphologically identified. A pure culture of the putativepathogen was tested for pathogenicity. A Completely Randomized Design (CRD) was performed with 4 replications. The rice var. Sen Pidoa was used for the pathogenicity test. The pathogen inoculums of $C$. lunata was cultured on potato dextrose agar (PDA) and incubated for 10 days at room temperature approximately $\left(30-33^{\circ} \mathrm{C}\right)$. The inoculums was adjusted to $1 \times 10^{6}$ spores/mL before spray-inoculating 20-day-old rice seedlings. Brown leaf spot symptoms were monitored and evaluated using a disease index as follows: $1=$ no symptoms $0 \%, 2=$ small blighted spots $1-25 \%$, $3=$ dead cells in the area of blighted spots (1-2 $\mathrm{mm}$ ) which turned brown 26-50\%, 4=expanded oval-shaped lesions $(1-2 \mathrm{~cm})$ and cell death in the center of lesion $51-75 \%$ and $5=$ diseased area over $76 \%$.

\section{Dual culture antagonistic test}

Chaetomium cupreum CC3003 wasobtained from Assoc. Prof. Dr. Kasem Soytong. This promising antagonist was tested for inhibition of $C$. lunata causing brown leaf spot of rice var. Sen Pidoa. The experiment was done using the dual culture antagonistic test which was arranged in a CRD with 4 replications, fol-
Correspondence: Huyly Tann, Department of Plant Production Technology, Faculty of Agricultural Technology, King Mongkut's Institute of Technology Ladkrabang Bangkok, Chalongkrung Road, Ladkrabang, Bangkok 10520 , Thailand.

Tel.: +855.698.98655/+855.128.98655.

E-mail: ajanhuylee@gmail.com

Key words: Brown leaf spot; Chaetomium sp.; Rice.

Acknowledgements: this is a part of $\mathrm{PhD}$ research and corresponding author would like to express his sincere thanks to all advisory committee for their encouragement of this research.

Contributions: the authors contributed equally.

Conflict of interest: the authors declare no potential conflict of interest.

Received for publication: 16 January 2016 . Accepted for publication: 25 January 2016.

This work is licensed under a Creative Commons Attribution-NonCommercial 4.0 International License (CC BY-NC 4.0).

(C) Copyright H.Tann and K. Soytong., 2016 Licensee PAGEPress srl, Italy

International Journal of Plant Biology 2016; 7:6413 doi:10.4081/pb.2016.6413

lowing previous studied methods. ${ }^{11,12}$ The antagonistic fungus and pathogen were cultured on PDA at room temperature $\left(30-32^{\circ} \mathrm{C}\right)$ for 7 days. A $0.5 \mathrm{~cm}$ diameter sterilized cork borer was used to remove an agar plug at the periphery of thepathogen and antagonistic fungus colonies. The agar plug of the pathogen was transferred to one side of a PDA plate and an agar plug of an antagonistic fungus to the opposite side. PDA plate with a single plug of an antagonistic fungus or thepathogen served as the controls. All plates were incubated at room temperature and abnormal spores and normal spores of pathogen in each treatment were recorded under a binocular compound microscope. Data included colony diameter (cm) and the number of pathogen spores which were counted using by haemacytometer. Percentage inhibition of colony growth andspore production of $C$. lunata were computed according to the following formula: \% inhibition (colony diameter or spore production of pathogen in control plate - colony diameter or spore production of pathogen in the dual culture plate) / colony diameter or spore production of pathogen in control plate $\times 100$. Colony diameter and spore production were statistically computed using analysis of variance. Treatment means were compared using Duncan's Multiple Range Test (DMRT) at $\mathrm{P}=0.05$ and 0.01 . 
In vitro antifungal metabolites from Chaetomium cupreum $\mathrm{CC} 3003$ against Curvularia lunata

Fungal growth and crude extracts C.cupreum CC3003 was cultured in potato dextrose broth (PDB) and incubated at room temperature $\left(28-30^{\circ} \mathrm{C}\right)$ for 4 weeks. Fungal biomasses were removed from the liquid by cheesecloth filtration and dried over night at $28-32^{\circ} \mathrm{C}$. The extraction was performed by the method described by Kanokmedhakul et al. ${ }^{13}$ The air-dried fungal biomass was ground and extracted with hexane (1:1 vol) and incubated by shaking for 24 hat room temperature. The solvent was separately taken out of the marc by filtration through filter paper (Whatman No.4). The marc from hexane extraction was extracted with ethyl acetate (EtOAc) and followed with methanol $(\mathrm{MeOH})$ using the same procedure as hexane. The solvents were separately evaporated to yield crude hexane, EtOAc and $\mathrm{MeOH}$ extracts.

In vitro antifungal metabolites from Chaetomium cupreum CC3003 against Curvularia lunata was done by using the poison agar method. ${ }^{14}$ The experiment was done by using a two-factor factorial experiment arranged in a CRD with four replications. Factor A represented crude hexane, EtOAc and $\mathrm{MeOH}$ extracts. Each crude extract was dissolved with $2 \%$ dimethyl sulfoxide (DMSO) to test for antifungal activity against the growth and spore production of $C$. lunata on potato dextrose agar (PDA) at concentrations of 0,10 , 50, 100, 500 and $1000 \mathrm{~g} / \mathrm{mL}$ (Factor B). Agar plugs (3-mm-dia) of $C$. lunata was cut from the advance margin of a 7-days-old colony and subcultured to the middle of PDA plate containing each concentration of the crude extract and incubated at room temperature. Other data collected were colony diameter $(\mathrm{cm})$ and spore production. Data were computed by analysis of variance (ANOVA), and treatment means were compared using the DMRT at $\mathrm{P}=0.01$. The effective dose of $\mathrm{ED}_{50}$ values was computed using probity analysis.

\section{Testing fungal metabolites from Chaetomium cupreum CC3003 to inhibit Curvularia lunata causing leaf spot of rice var. Sen Pidoa in a pot experiment}

The experiment was performed by using Randomized Complete Block Design (RCBD) with four replications. Treatments were set up as follows: inoculated with $C$. lunata (T1), inoculated and applied spore suspension of $C$. cupreum CC3003 $1-10^{6}$ spore/mL (T2), biofungicide (C. cupreum CC3003) at $20 \mathrm{~g} / 20 \mathrm{~L}$ of water (T3), nano-particle of $C$. cupreum CC3003 (T4) and chemical fungicide (tebuconasole) $0.1 \mathrm{~mL} / 1 \mathrm{~L}$ of water (T5). Rice seeds var. Sen Pidoa were soaked in sterile water for 24 hours in moisten paper until germination, then planted into pots ( 3 seedlings per pot). The 15-day-old rice seedlings were inoculated by wounding leaves and applying a $1 \times 10^{6}$ spore/mL; three wounded leaves/seedlings were done. Each treatment was applied as mentioned above at every 15 days until harvest.

\section{Preparation of nano-particles from Chaetomium cupreum CC3003}

Nano-particles from C. cupreum CC3003 were obtained from Joselito Dar and Kasem Soytong (KMITL, Bangkok, Thailand) who firstly investigated these new nano-particles which were developed and characterized nano materials loaded with active compounds from Chaetomium sp. Crude extracts from $C$. cupreum CC3003 were used in this study. The extracts were incorporated into poly acetic acid and electro spin at 25-30 kv. The product from C. cupreum CC3003 was pale orange in color. Scanning electron microscope images revealed that the nano material from $C$. cupreum measured 171 nanometers.

Data were collected as plant height $(\mathrm{cm})$, number of tillers. The leaf spot disease index (DI) consisted of the following rating scheme: $1=$ no symptoms $0 \%, 2=$ small blighted spots 1 $25 \%, 3=$ dead cells in the area of blighted spot 1-2 mm which turned brown 26-50\%, $4=$ expanded lesion in oval shape $1-2 \mathrm{~cm}$ and cell death in the center of lesion $51-75 \%$ and $5=$ diseased area over $76 \%$, which was modified from Soytong et al..$^{9}$ Data were computed by ANOVA and treatment means were compared using DMRT at $\mathrm{P}=0.05$ and $\mathrm{P}=0.01$.

\section{Field experiment}

The experiment was conducted by using a RCBD with 4 replications; and 4 treatments were done as follows: the non-treated control (T1), organic method (T2), GAP method (T3) and chemical method (T4).The non-treated control did not use any bio-products or chemicals. Organic method used nano-particles of $C$. cupreum (10 cc/20 L of water), applied organic fertilizer $4.5 \mathrm{~kg} / \mathrm{plot}$, liquid biofertilizer 40 cc/20 L, bioinsecticide (Metarhizium sp. and Beauveria sp.) (50 cc/20 L of water) every 20 days until harvest.

The GAP method (good agricultural practice) used the chemical-organic biofertilizer (12-3-3) $1.5 \mathrm{~kg} /$ plot, spraying bio-insecticide together with the nano-product of Chaetomium at the rate of $10 \mathrm{cc} / 20 \mathrm{~L}$ alternated with the chemical insecticide (buprofezin 25\%WP $30 \mathrm{~g} / 20 \mathrm{~L}$ ) together with the chemical fungicide (tebuconazole $20 \mathrm{cc} / 20 \mathrm{~L}$ ) every 20 days until harvest. The chemical method applied urea $46-0-0(0.75 \mathrm{~kg} / \mathrm{plot})$ in the early stage and 15-15-15 before the flowering stage
( $0.75 \mathrm{~kg} / \mathrm{plot})$ and buprofezin 25\%WP (30 g/20 L) together with tebuconazole $(20 \mathrm{cc} / 20 \mathrm{~L})$ every 20 days until harvest. Disease index of leaf spot was recorded as in the pot experiment. Other data collected were plant height (cm), number of tillers, panicle number/plant, panicle length $(\mathrm{cm})$ and panicle weight $(\mathrm{g})$, grain weight/plot $(\mathrm{kg})$ and dried hay weight (kg). Data were computed by analysis of ANOVA and treatment means were compared using DMRT at $\mathrm{P}=0.05$ and $\mathrm{P}=0.01$.

\section{Results \\ Isolation of pathogen pathogenicity test}

Curvularia lunata was isolated from leaf spot of rice in var. Sen Pidoa in this study and demonstrated to be pathogenic on this host.

\section{Dual culture antagonistic test}

Chaetomium cupreum CC3003 significantly inhibited $C$. lunata causing leaf spot of rice in the dual culture test; spore production of pathogen was $151.38 \times 10^{6} \mathrm{spores} / \mathrm{mL}$ in dual culture and $256.72 \times 151.38 \times 10^{6}$ spores $/ \mathrm{mL}$ in control plate which significantly inhibited by $41 \%$ when compared to the control plate.

\section{In vitro antifungal metabolites from Chaetomium cupreum CC3003 \\ against Curvularia lunata}

Antifungal metabolites from $C$. cupreum CC3003 inhibited the growth and spore production of $C$. lunata causing leaf spot of rice as shown in Table 1.

The extraction of antifungal metabolites from $C$. cupreum using hexane, ethyl acetate (EtOAc) and methanol inhibited spore production at $1000 \mu \mathrm{g} / \mathrm{mL}$ by $95.14 \%, 94.93 \%$ and $87.91 \%$, respectively. The $\mathrm{ED}_{50}$ values of hexane, EtOAc and methanol extracts from $C$. cupreum CC3003 were 6.41, 0.83 and 7.81 $\mu \mathrm{g} / \mathrm{mL}$, respectively (Table 1 ).

It was clearly shown under the compound microscope that the pathogen spores were abnormal due to antagonistic substances extracted with hexane, EtOAc and methanol extracts from C. cupreum CC3003 released into pathogen cells (Figure 1).

Testing fungal metabolites to inhibit Curvularia lunata causing leaf spot in rice var. Sen Pidoa in pot experiment

The results showed that the height of plants treated with a spore suspension of $C$. cupreum, bioformulation of $C$. cupreum, nano particles of $C$. cupreum and the chemical fungicide (tebuconazole) were significantly higher than the inoculated controls at 65 days after plant- 
ing (Table 2) which were 28.49, 28.92, 28.04 and $27.16 \mathrm{~cm}$, respectively when compared to the inoculated control $(26.91 \mathrm{~cm})$. It was clearly demonstrated that treatment with a spore suspension of $C$. cupreum, bio formulation of $C$. cupreum, nano particles of $C$. cupreum and the chemical fungicide (tebuconazole) gave higher number of tillers which were $9.25,9.63$, 9.88 and 9.94 , respectively, than the inoculated controls (6.00). All treatments increased the number of tillers from $35.14 \%$ to $39.64 \%$ when compared to the inoculated control (Table 2).
Rice seedlings treated with a spore suspension of $C$. cupreum, bioformulation of $C$. cupreum, nano particles of $C$. cupreum and the chemical fungicide (tebuconazole) showed significantly lower disease indices (DI) of $1.75,1.50,1.50$ and 1.25 , respectively, than the
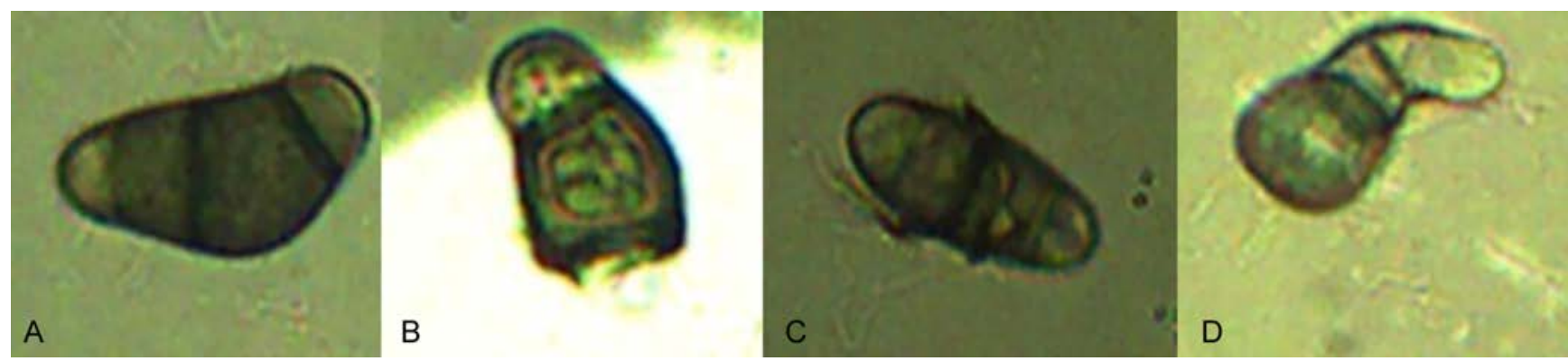

Figure 1. Effects of hexane, EtoAC and methanol extracts from C. cupreum CC3003 on spores of C. lunata. A) $0 \mu \mathrm{g} / \mathrm{mL}$; B) Hexanecrude extract $1000 \mu \mathrm{g} / \mathrm{mL}$; C) EtOAC-crude extract $1000 \mu \mathrm{g} / \mathrm{mL}$; D) Methanol-crude extract $1000 \mu \mathrm{g} / \mathrm{mL}$.

Table 1. Antifungal metabolites from Chaetomium cupreum CC3003 against Curvularia lunata.

\begin{tabular}{|c|c|c|c|c|c|c|}
\hline Crude extracts & $\begin{array}{l}\text { Conc. } \\
\text { ( } \mu g / m L)\end{array}$ & $\begin{array}{c}\text { Colony } \\
\text { diameter (cm) }\end{array}$ & $\begin{array}{c}\text { Spore number } \\
\left(10^{6} \mathrm{cfu} / \mathrm{mL}\right)\end{array}$ & $\begin{array}{c}\text { Colony } \\
\text { inhibition* }\end{array}$ & $\begin{array}{c}\text { Spore } \\
\text { inhibition* }\end{array}$ & $\begin{array}{c}E_{50} \\
(\mu g / m L)\end{array}$ \\
\hline Hexane-crude extract & $\begin{array}{l}0 \\
10 \\
50 \\
100 \\
500 \\
1000\end{array}$ & $\begin{array}{c}5.00^{\mathrm{a}^{*}} \\
4.38^{\mathrm{bc}} \\
4.23^{\mathrm{def}} \\
4.14^{\mathrm{fg}} \\
4.05^{\mathrm{gh}} \\
3.84^{\mathrm{i}}\end{array}$ & $\begin{array}{c}77.00^{\mathrm{a}} \\
64.25^{\mathrm{c}} \\
46.88^{\mathrm{d}} \\
30.00^{\mathrm{f}} \\
9.88^{\mathrm{j}} \\
3.75^{\mathrm{l}}\end{array}$ & $\begin{array}{c}0.00^{\mathrm{j}} \\
12.45^{\mathrm{hi}} \\
15.40^{\mathrm{efg}} \\
17.20^{\mathrm{de}} \\
19.00^{\mathrm{cd}} \\
23.10^{\mathrm{b}}\end{array}$ & $\begin{array}{c}0.001 \\
16.56^{\mathrm{k}} \\
39.21^{\mathrm{j}} \\
61.06^{\mathrm{h}} \\
87.20^{\mathrm{c}} \\
95.14^{\mathrm{a}}\end{array}$ & 6.41 \\
\hline Ethyl acetate-crude extract & $\begin{array}{l}0 \\
10 \\
50 \\
100 \\
500 \\
1000\end{array}$ & $\begin{array}{c}5.00^{\mathrm{a}} \\
4.48^{\mathrm{b}} \\
4.34^{\mathrm{cd}} \\
4.28^{\mathrm{cde}} \\
4.01^{\mathrm{h}} \\
3.60^{\mathrm{j}}\end{array}$ & $\begin{array}{c}71.50^{\mathrm{b}} \\
21.50^{\mathrm{g}} \\
12.63^{\mathrm{i}} \\
9.63^{\mathrm{j}} \\
6.88^{\mathrm{k}} \\
3.63 \mathrm{l}\end{array}$ & $\begin{array}{c}0.00^{\mathrm{j}} \\
10.50^{\mathrm{i}} \\
13.10^{\mathrm{gh}} \\
14.50^{\text {fgh }} \\
19.85^{\mathrm{c}} \\
28.00^{\mathrm{a}} \\
\end{array}$ & $\begin{array}{c}0.001 \\
69.91^{\mathrm{f}} \\
82.35^{\mathrm{d}} \\
86.54^{\mathrm{c}} \\
90.38^{\mathrm{b}} \\
94.93^{\mathrm{a}}\end{array}$ & 0.83 \\
\hline Methanol-crude extract & $\begin{array}{l}0 \\
10 \\
50 \\
100 \\
500 \\
1000\end{array}$ & $\begin{array}{c}5.00^{\mathrm{a}} \\
4.46^{\mathrm{b}} \\
4.30^{\mathrm{cde}} \\
4.21^{\mathrm{ef}} \\
4.13^{\mathrm{fg}} \\
4.01^{\mathrm{h}}\end{array}$ & $\begin{array}{c}78.5^{\mathrm{a}} \\
37.38^{\mathrm{e}} \\
28.50^{\mathrm{f}} \\
18.63^{\mathrm{h}} \\
14.00^{\mathrm{i}} \\
9.50^{\mathrm{j}}\end{array}$ & $\begin{array}{c}0.00^{\mathrm{j}} \\
10.70^{\mathrm{i}} \\
13.95^{\mathrm{fgh}} \\
15.75^{\mathrm{ef}} \\
17.45^{\mathrm{de}} \\
19.70^{\mathrm{c}}\end{array}$ & $\begin{array}{c}0.001 \\
52.38^{\mathrm{i}} \\
63.69^{\mathrm{g}} \\
76.28^{\mathrm{e}} \\
82.15^{\mathrm{d}} \\
87.91^{\mathrm{c}}\end{array}$ & 7.81 \\
\hline C.V.(\%) & & 1.74 & 4.47 & 10.74 & 2.37 & \\
\hline
\end{tabular}

*Means of four replication, means followed by a common letter were not significantly different by DMRT at $\mathrm{P}=0.01$.

Table 2. Number of tillers, plant height and disease index of rice var. Sen Pidoa in a pot experiment at 65 days.

\begin{tabular}{lcccccc}
\hline Treatments & $\begin{array}{l}\text { Number of tillers } \\
\text { \% increase }\end{array}$ & $\begin{array}{c}\text { Plant height } \\
(\mathrm{cm})\end{array}$ & $\begin{array}{c}\text { \% increase } \\
\text { DI }{ }^{2}\end{array}$ & $\begin{array}{c}\text { Disease reduction } \\
(\%)\end{array}$ \\
Inoculated control & $6.00^{\mathrm{c}}$ & 0.00 & $26.91^{\mathrm{a}}$ & 0.00 & $3.00^{\mathrm{a}^{*}}$ & - \\
Spore suspension of C. cupreum & $9.25^{\mathrm{a}}$ & 35.14 & $28.49^{\mathrm{a}}$ & 5.55 & $1.75^{\mathrm{ab}}$ & 41.66 \\
\hline Bioformulation of C. cupreum & $9.63^{\mathrm{a}}$ & 37.69 & $28.92^{\mathrm{a}}$ & 6.95 & $1.50^{\mathrm{b}}$ & 50.00 \\
Nano particles of C. cupreum & $9.88^{\mathrm{a}}$ & 39.27 & $28.04^{\mathrm{a}}$ & 4.03 & $1.50^{\mathrm{b}}$ & 50.00 \\
\hline Tebuconazole - chemical fungicide & $9.94^{\mathrm{a}}$ & 39.64 & $27.16^{\mathrm{a}}$ & 0.92 & $1.25^{\mathrm{b}}$ & 58.33 \\
C.V.(\%) & 14.36 & - & 7.35 & - & 3.11 & - \\
\hline
\end{tabular}

* Means of four replications. Means followed by a common letters are not significantly different by DMRT at $\mathrm{P}=0.01$. Disease Index 2 (DI) was rated using the following scheme: $1=$ no symptoms $0 \%$, $2=$ small blighted spots 1-25\%, $3=$ dead cells in the area of blighted spots $1-2 \mathrm{~mm}$ and turning brown $26-50 \%, 4=$ expanded oval-shaped lesions $1-2 \mathrm{~cm}$ and cell death in the center of lesion $51-75 \%$, and $5=$ diseased area over $76 \%$. Modified from Soytong \& Quimio, 1989.9 
Table 3. Disease index (DI) of leaf spot caused by Curvularia lunata on rice var. Sen Pidoa in field experiment.

\begin{tabular}{|c|c|c|c|c|}
\hline Treatments & DI on leaves* & $\begin{array}{l}\text { DI in grains } \\
\text { and panicles }\end{array}$ & $\begin{array}{c}\text { Disease reduction } \\
\text { on leaves (\%) }\end{array}$ & $\begin{array}{c}\text { Disease reduction } \\
\text { on grains (\%) }\end{array}$ \\
\hline Non treated control & $5.00^{\mathrm{a}^{* *}}$ & $5.00^{\mathrm{a}}$ & - & - \\
\hline Organic method & $3.00^{\mathrm{b}}$ & $3.00^{\mathrm{b}}$ & 40 & 40.00 \\
\hline GAP method & $3.00^{\mathrm{b}}$ & $3.33^{\mathrm{b}}$ & 40 & 33.40 \\
\hline Chemical method & $2.00^{c}$ & $1.66^{\mathrm{c}}$ & 60 & 66.80 \\
\hline C.V.(\%) & 12.92 & 16.74 & & \\
\hline
\end{tabular}

Table 4. Growth parameters of rice var. Sen Pidoa in the field trial at 80 days.

\begin{tabular}{|c|c|c|c|c|c|}
\hline Treatments & Plant height & Tiller number & $\begin{array}{c}\text { Panicle number/ } \\
\text { plant }\end{array}$ & $\begin{array}{l}\text { Panicle length } \\
(\mathrm{cm})\end{array}$ & $\begin{array}{l}\text { Panicle weight } \\
\text { (g) }\end{array}$ \\
\hline Non treated control & $61.40^{\mathrm{b}}$ & $g^{b}$ & $9^{c^{*}}$ & $16.85^{c}$ & $1.65^{\mathrm{c}}$ \\
\hline Organic method & $63.40^{\mathrm{ab}}$ & $16^{\mathrm{a}}$ & $15^{b}$ & $19.45^{b}$ & $2.10^{\mathrm{b}}$ \\
\hline GAP method & $66.05^{\mathrm{ab}}$ & $21^{\mathrm{a}}$ & $21^{\mathrm{a}}$ & $19.67^{\mathrm{b}}$ & $2.25^{\mathrm{ab}}$ \\
\hline Chemical method & $69.20^{\mathrm{a}}$ & $22^{\mathrm{a}}$ & $18^{\mathrm{a}}$ & $21.25^{\mathrm{a}}$ & $2.35^{\mathrm{a}}$ \\
\hline $\mathrm{CV}(\%)$ & 3.97 & 9.62 & 7.06 & 2.24 & 6.21 \\
\hline
\end{tabular}

*Means of four replications. Means followed by a common letters are not significantly different by DMRT at $\mathrm{P}=0.01$.

inoculated control (DI=3.00). All treatments reduced disease by $41.66 \%$ to $58.33 \%$ compared to the inoculated control (Table 2).

\section{Field experiment}

The results showed that the chemical method significantly reduced leaf spot disease caused by C. lunata by $60 \%$, followed by organic method (40\%) and GAP methods (40\%), respectively (Table 3). It was found that plant height at 80 days were not significantly different among the organic, GAP and chemical methods when compared to the non-treated control (Table 4). The panicle number per plant in chemical and GAP methods were significantly higher than organic method when compared to the non-treated control. The panicle length in chemical method $(21.25 \mathrm{~cm})$ was significantly higher than GAP and organic methods which were 19.67 and $19.45 \mathrm{~cm}$, respectively when compared to the non-treated control $(16.85 \mathrm{~cm})$. The panicle weights $(2.35 \mathrm{~g})$ in chemical method was significantly higher than organic and GAP methods which were 2.10 and $2.25 \mathrm{~g}$, respectively when compared to the non-treated control (1.65 g) as seen in Table 4. With this, the chemical and GAP methods were significantly higher in grain weight (10.77 and $10.26 \mathrm{~kg} / 20 \mathrm{~m}^{2}$ ) than the organic method $\left(7.37 \mathrm{~kg} / 20 \mathrm{~m}^{2}\right)$ when compared to the non treated control $\left(4.12 \mathrm{~kg} / 20 \mathrm{~m}^{2}\right.$; Table $5)$. The dried weight of hay in chemical (17.21 $\left.\mathrm{kg} / 20 \mathrm{~m}^{2}\right)$ and GAP $\left(16.42 \mathrm{~kg} / 20 \mathrm{~m}^{2}\right)$ methods were also was significantly higher in organic method $\left(9.40 \mathrm{~kg} / 20 \mathrm{~m}^{2}\right)$ when compared to the non treated control $\left(6.17 \mathrm{~kg} / 20 \mathrm{~m}^{2}\right)$ as seen in Table 5.

Table 5. Grain weight and dried hay weight of rice var. Sen Pidoa in the field trial at 80 days.

\begin{tabular}{lcc} 
Treatments & $\begin{array}{c}\text { Grain weight } \\
(\mathrm{kg}) / 20 \mathrm{~m}^{2}\end{array}$ & $\begin{array}{c}\text { Dry hay weight } \\
(\mathrm{kg}) / 20 \mathrm{~m}^{2}\end{array}$ \\
Non treated control & $4.12^{\mathrm{c}}$ & $6.17^{\mathrm{c}}$ \\
Organic method & $7.37^{\mathrm{b}}$ & $9.40^{\mathrm{b}}$ \\
\hline GAP method & $10.26^{\mathrm{a}}$ & $16.42^{\mathrm{a}}$ \\
Chemical method & $10.77^{\mathrm{a}}$ & $17.21^{\mathrm{a}}$ \\
\hline C.V.(\%) & 6.54 & 14.44 \\
\hline
\end{tabular}

Means of four replications. Means followed by a common letters were not significantly different by DMRT at P=0.01.

\section{Discussion and Conclusions}

Curvularia lunata was found to seriously infected rice var. Sen Pidoa in the field in Cambodia and this research finding is confirmed by isolation of pathogenic isolate and proved pathogenicity test. It is reported for the first time in Cambodia. Ou stated that $C$. luna$t a$ is one of the most commonly found fungi in rice seeds leading to grain discoloration and, ${ }^{15}$ Kamaluddeen et al. and Alcorn reported that $C$. lunata is caused leaf spot or leaf blight of rice and other hosts. ${ }^{1,16}$ In this study showed that $C$. cupreum significantly inhibited $C$. lunata isolated from leaf spot of rice var. Sen Pidoa. Soytong et al. ${ }^{17}$ reported that $C$. cupreum was antagonistic to the rice blast pathogen caused by Pyricularia oryzae in the Philippines.

Fungal metabolites released from $C$. cupreum CC3003 used isolate in this study was studied by Kanokmedhakul et al., ${ }^{13}$ who report- ed that it produces three new azaphilones named rotiorinols A-C (1-3), two new stereoisomers, (-)-rotiorin (4) and epiisochromophilone II (5), and a known compound, rubrorotiorin (6). Compounds 1, 3, 4, and 6 exhibited antifungal activity against Candida albicans with $\mathrm{IC}_{50}$ values of $10.5,16.7$, 24.3 , and $0.6 \mathrm{ug} / \mathrm{mL}$, respectively. It is suggested that $C$. cupreum could produce and release these bioactive compounds against $C$. lunata. Moreover, Tathan reported that crude extracts of $C$. cupreum CC3003 expressed antifungal activity against Dreschera oryza causing leaf blight of rice. ${ }^{18}$ It was shown that the pathogen spores were abnormal due to metabolites from C. cupreum CC3003 extracted with hexane, EtOAc and methanol could destroy the pathogen cells. As a result, Soytong et al. ${ }^{9}$ reported this phenomenon, namely antibiosis and lyses, that fungal-derived antagonistic substances could destroy the pathogen cells leading to loss of pathogenicity. Moreover, 
Soytong et al. ${ }^{7}$ stated that metabolites produced by Chaetomium spp. inhibited several plant pathogens including $C$. lunata. Similar result reported by Tathan, ${ }^{18}$ stated that the metabolites from Chaetomium spp. could inhibit Drechslera oryzae which causes leaf spot of rice.

The results demonstrated that rice seedlings var. Sen Pidoa treated with a spore suspension of $C$. cupreum, bioformuation of $C$. cupreum, nano particles of $C$. cupreum and the chemical fungicide (tebuconazole) revealed significantly lower disease indices than the inoculated control. The plant heights treated with a spore suspension of $C$. cupreum, bio formulation of $C$. cupreum, nano particles of $C$. cupreum and the chemical fungicide (tebuconazole) were significantly higher than the inoculated controls at 65 days after planting. Similar report stated by Soytong et al. ${ }^{19}$ that a bioformulation of Chaetomium cochliodes gave good control of brown leaf spot of rice caused by Curvularia lunata.

The field trial results showed that the chemical method gave better reduction of leaf spot disease caused by $C$. lunata than organic and GAP methods. But mostly growth parameters at 80 days were not significantly different among the organic, GAP and chemical methods when compared to the non-treated control. As a result, the chemical and GAP methods were significantly higher in grain weight than the organic method when compared to the non treated control. This result is contradicted to previous study by Tann et al., ${ }^{20}$ who reported that organic method trended to be higher yield than GAP and chemical methods. It is recommended that it could be affected by variable factors such as water management, weeding, soil type and soil fertility in different location.

Curvularia lunata is reported for the first time to cause leaf spots of rice var. Sen Pidoa in Cambodia. Chaetomium cupreum CC3003 can be significantly inhibited $C$. lunata in dual culture test. The antifungal metabolites from C. cupreum expressed antifungal activity against $C$. lunata at the $\mathrm{ED}_{50}$ values of hexane, Et0Ac and methanol crude extracts were 6.41 , 0.83 and $7.81 \mu \mathrm{g} / \mathrm{mL}$, respectively. In pot experiment, it was shown that treatment with a spore suspension of $C$. cupreum, bio formulation of $C$. cupreum, nano particles of $C$. cupreum and the chemical fungicide (tebuconazole) gave higher growth parameters than the inoculated controls. Rice seedlings treated with a spore suspension of $C$. cupreum, bioformulation of $C$. cupreum, nano particles of $C$. cupreum and the chemical fungicide tebuconazole showed significantly lower disease incidence than the inoculated control. Field experiment showed that the chemical method was better reduction leaf spot disease caused by $C$. lunata than organic and GAP methods. The chemical and GAP methods gave higher in grain weight than the organic method when compared to the non-treated control.

\section{References}

1. Kamaluddeen SS, Abhilasha AL. A new blight disease of rice caused by Curvularia lunata from Uttar Pradesh. Int J Agricult Sci Res 2013;3:13-6.

2. Groves JW, Skolko AJ. Notes on seed borne fungi. III. Curvularia. Can J Res 1945; 23:94-104.

3. Patwick G W. Manual of rice diseases. Kew: CMI; 1950. p. 198.

4. Martin, AL. Possible cause of black kernels in rice. Plant Dis Rep 1939;23:247-4.

5. Lakshmanan P. Sheath rot of rice incited by curvularia lunata in Tamil Nadu, India. Trop Pest Manag 1992;38:107.

6. Akram WT, Anjum A, Moeen AR. First report of Curvularia lunata causing leaf spots on sorghum bicolor from Pakistan. Plant Dis 2014;98:1007.

7. Soytong K, Kanokmedhakul S, Kukongviriyapaa V, Isobe M. Application of Chaetomium species (Ketomium) as a new broad spectrum biological fungicide for plant disease control: a review article. Fungal Divers 2011;7:1-15.

8. Alford J, Duguid N. Seductions of rice. New York: Artisan Publishers; 1998. Gramene Reference ID 8382.

9. Soytong K, Quimio TH. Antagonism of
Chaetomium globosum to the rice blast pathogen, Pyricularia oryzae. Kasetsart J (Nat Sci) 1989;23:198-203.

10. Tann H, Soytong K, Makhonpas C, Adthajadee A. Comparison between organic, GAP and chemical methods for cultivation of rice varieties in Cambodia. $\mathrm{J}$ Agricult Technol 2011;7:2239-45.

11. Soytong K. Biological control of rice blast disease by seed coating with antagonistic fungi. Sci Technol 1992:59-65.

12. Charoenporn C, Kanokmedhakul S, Lin FC, et al. Evaluation of bio-agent formulations to control Fusarium wilt of tomato. Afr J Microbiol Res 2010;9:5836-44.

13. Kanokmedhakul SK, Nasomjai P, Loungsysouphanh S, et al. Antifungal azaphilones from the fungus, Chaetomium cupreum CC3003. J Nat Prod 2006;69:891-5.

14. Soytong K, Kanokmedhakul S, Kukongviriyapaa V, Isobe M. Application of Chaetomium species (Ketomium) as a new broad spectrum biological fungicide for plant disease control: a review article. Fungal Divers 2011;7:1-15.

15. Ou SH. Rice disease. $2^{\text {nd }}$ ed. Kew, Surrey: Commonwealth Mycological Institute; 1985.

16 Alcorn JL. New combination and synonymy in Bipolaris and Curvularia, and a newspecies of Exserohilum, Mycotaxon XLI 1991; NO. 2, pp. 329-343.

17. Soytong K. Antagonism of Chaetomium cupreum to Pyricularia oryzae. J Plant Protect Tropics 1992;9:17-23.

18. Tathan S, Sibounnavong P, Sibounnavong PS, et al. Biological metabolites from Chaetomium sp. to inhibit Drechslera oryzae causing leaf spot of rice. J Agric Technol 2012;8:1691-701.

19. Soytong K. Bioformulation of Chaetomium cochliodes for controlling brown leaf spot of rice. J Agric Technol 2014;10:321-37.

20. Tann H, Makhonpas C, Utthajadee A, Soytong K. Effect of good agricultural practice and organic methods on rice cultivation under the system of rice intensification in Cambodia. J Agric Technol 2012;8: 289-303. 